\title{
On the Relationship between Bank Lending Indicators and General Economic Indicators
}

\author{
Yury Korobov ${ }^{1, *}$, Sergey Bogomolov ${ }^{1}$, Larisa Ilyina $^{1}$, and Marina Plotnikova ${ }^{1}$ \\ ${ }^{1}$ Yuri Gagarin State Technical University of Saratov, Socio-Economic Institute, Department of \\ Banking, Money \& Credit, Saratov, Russia
}

\begin{abstract}
One of the most important tasks of any state is to ensure stable economic growth. Banks can play an important role in performing this task, primarily by providing loans. The purpose of the study is to identify the relationship between indicators of banks' lending activity and general indicators of economic development. Index of physical volume of GDP and index of physical volume of fixed capital investment were selected as resultant economic indicators, and growth rate of debt on bank loans (overall and by loan types), the share of loans in fixed capital investment, and the ratio of debt on bank loans to GDP were used as factor variables. The study of the dynamics of these indicators showed that the trajectory of economic indicators has a general tendency to decrease their values; the dynamics of economic indicators depends more on bank lending to legal entities than on lending to individuals, and often reflects the change in the share of loans in fixed capital investment with a time lag; economic growth is more strongly influenced by bank lending to legal entities than by lending to individuals. The revealed patterns indicate the need to develop a monetary policy aimed at stimulating corporate lending and moderate curbing consumer lending.
\end{abstract}

Keywords: bank, lending, economic indicators, investment, gross domestic product.

\section{Introduction}

Ensuring stable economic growth and at the same time creating conditions for a positive role of banks in its implementation is one of the most important tasks of any state, including Russia. In the President's message to the Federal Assembly of Russian Federation in 2020, the idea of the need for active participation of banks in solving largescale socio-economic problems facing the country was voiced several times. In particular, banks are encouraged to implement preferential mortgage programs. In addition, one of the measures proposed to launch a new investment cycle, which implies an annual increase in investment of at least $5 \%$ and achieve a ratio of investment to gross domestic product (GDP) at $25 \%$ by 2024 , is to ensure the availability of long-term money by increasing the availability of credit in the real sector of the economy. It is worth noting that in Russian

*Corresponding author: yurikor1965@gmail.com 
Financial Market Development Program for 2019-2021 [1], ensuring access to financial services and capital is also identified as one of the main tasks of the Bank of Russia. At the same time, within the framework of this document, it is advisable to form a development strategy for each component of the financial market, including the credit market as its most significant sector [2]. In another strategic document - Monetary Policy Guidelines for 2020-2022 [3], Bank of Russia emphasizes that its monetary policy creates conditions for accelerating economic growth, but cannot affect the economic potential itself, which depends primarily on productivity of labor and capital, and the speed of introduction of new technologies.

Considering these guidelines for the near term, it is important to identify the relationship between the rate of economic growth and development of bank lending. In this regard, the purpose of this study is to identify the relationship between indicators of banks' lending activity and general indicators of economic development in Russia.

The objectives of the study are: 1) to assess the trajectory of the dynamics of economic indicators in Russia for the period 2000-2018; 2) to analyze the evolution of bank lending indicators for the same period; 3 ) to compare the dynamics of general economic indicators and bank lending indicators in order to identify the relationship between them; 4) to determine the specific patterns of this relationship; 5) to formulate guidelines for monetary policy, taking into account the revealed patterns.

\section{Literary Research}

Relationship between banks' lending activity and macroeconomic indicators is one of the most important topics of economic research. In our opinion, the theoretical basis of specific empirical studies based on quantitative data in this area can be considered scientific works in which the question of existence of any connection between credit and economic development was raised in the most general form. Thus, the classics of economic thought (Smith, Ricardo, etc.) attached great importance to production, but at the same time diminished the role of credit. On the contrary, Schumpeter, Hahn and others, overemphasized credit as the primary engine of economic development [4]. In accordance with the ideas of Marx [5], credit should not be put forward as the primary engine of economic development, but it can contribute to it. And, therefore, excessive lending is not the root cause of crises, but it can develop and exacerbate accumulated production problems. Keynes [6] emphasized that one of the consequences of the increase in bank lending is the expansion of production based on investment growth. Hayek [7], who investigated how credit expansion affects the production structure, came to the conclusion that credit expansion, which is not supported by a previous increase in voluntary savings, distorts the production structure, artificially making it excessively capital intensive, and ultimately leads to recessions [8].

Modern scientists also continue to study the relationship between lending activity and macroeconomic indicators. While some authors emphasize mutual causal relationship between lending dynamics and economic development [9], others detect influences of the macroeconomic environment on bank lending [10], but most researchers prove the dependence of economic growth on bank lending, focusing on lending to companies [11, $12,13,14,15,16,17,18]$. In particular, Lavrushin [19] examines in detail possible positive results of lending for the economy and negative consequences in case of illiterate handling of credit, and proposes a number of indicators to assess the role of credit in the economy.

Research in this area is also conducted by regulatory financial institutions. Thus, International Monetary Fund (IMF) representatives periodically prepare relevant reviews, and, in particular, in 2015, it was revealed to what extent credit growth is reflected in GDP growth in developing countries [20]. Bank of Russia experts found that an increase in loans 
to the real economy before reaching the threshold of $86 \%$ of GDP contributes to economic growth, while after passing this threshold, on the contrary, can lead to macroeconomic instability [21].

Thus, taking into account the results of these and other similar studies, we consider it necessary to study the peculiarities of the relationship between indicators of banks' lending activity and macroeconomic indicators on the basis of an extended list of factor variables, which is what this article is focused on.

\section{Data and methods}

Agreeing with the opinion that initially banks' lending activity influences economic development, we have selected as resultant (dependent) following economic indicators:

- Index of physical volume of GDP (hereinafter - GDP index);

- Index of physical volume of fixed capital investment (hereinafter - investment index).

As factor variables were chosen following bank lending indicators:

- Growth rate of debt on bank loans - overall and separately on loans to resident legal entities and to resident individuals (hereinafter - growth rate of bank loans);

- Share of loans in sources of fixed capital investment financing (hereinafter - share of loans in investment);

- Ratio of debt on bank loans (overall and by loan types) to GDP (hereinafter - ratio of bank loans to GDP).

The dynamics of these indicators was studied for the period 2000-2018 in Russia. Main data sources for the study were analytical materials of Bank of Russia, and Federal State Statistic Service.

The identification of the peculiarities of the relationship between selected resultant and factor variables required the use of graphical models, systems approach, comparative approach, dialectical method, deduction and induction.

\section{Results and discussion}

Comparative analysis of the dynamics of the GDP index and the investment index shows that their changes practically coincide and have a general tendency to decrease the values (Fig. 1). So, while for the periods 2000-2002, 2003-2005, 2006-2008 average values of these indices did not drop below 106\%, the periods 2009-2011, 2012-2014, 2015-2018 not even reached the level of $105 \%$ (Table 1). At the same time, the investment index is characterized either by a higher growth or by a larger decrease in comparison with the GDP index, which indicates its more noticeable sensitivity to both crisis phenomena and the emergence of favorable conditions for economic development. 


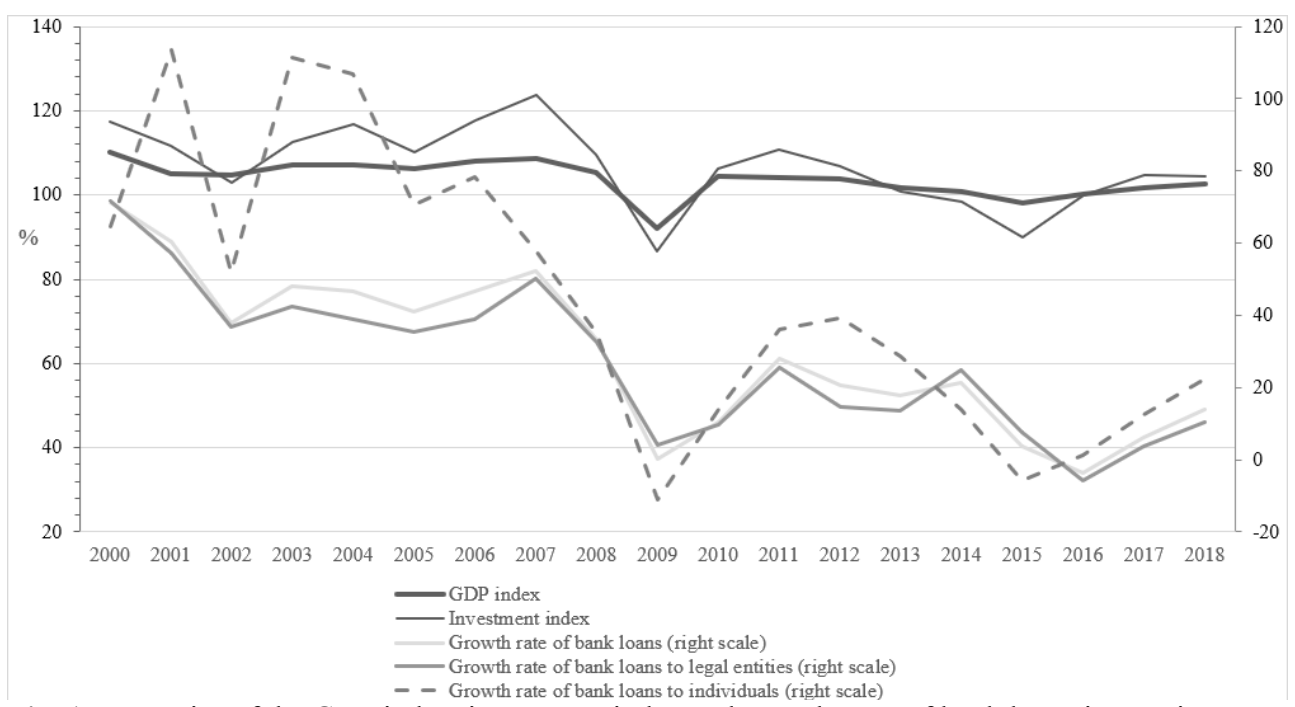

Fig. 1. Dynamics of the GDP index, investment index and growth rates of bank loans in Russia Source: Own processing based on data of Bank of Russia [22] and Federal State Statistic Service [23].

Table 1. Average values of general economic indicators and bank lending indicators in Russia

\begin{tabular}{|l|c|c|c|c|c|c|}
\hline \multirow{2}{*}{ Figure } & \multicolumn{7}{|c|}{ Average values for the periods: } \\
\cline { 2 - 7 } & $\begin{array}{c}2000- \\
2002\end{array}$ & $\begin{array}{c}2003- \\
2005\end{array}$ & $\begin{array}{c}2006- \\
2008\end{array}$ & $\begin{array}{c}2009- \\
2011\end{array}$ & $\begin{array}{c}2012- \\
2014\end{array}$ & $\begin{array}{c}2015- \\
2018\end{array}$ \\
\hline GDP index & 106.6 & 106.9 & 107.3 & 100.3 & 102.1 & 100.7 \\
\hline Investment index & 110.7 & 113.2 & 117.0 & 101.2 & 102.0 & 99.7 \\
\hline Growth rates of bank loans & 56.4 & 45.2 & 44.0 & 12.9 & 20.0 & 5.0 \\
\hline Share of loans in investment & 3.7 & 7.1 & 10.6 & 9.3 & 9.7 & 10.2 \\
\hline $\begin{array}{l}\text { Growth rate of bank loans to } \\
\text { legal entities }\end{array}$ & 55.2 & 38.8 & 40.6 & 13.0 & 17.8 & 4.0 \\
\hline $\begin{array}{l}\text { Growth rates of bank loans to } \\
\text { individuals }\end{array}$ & 76.6 & 96.2 & 57.1 & 13.1 & 27.3 & 7.6 \\
\hline Ratio of bank loans to GDP & 14.3 & 22.8 & 35.6 & 40.8 & 46.8 & 48.3 \\
\hline $\begin{array}{l}\text { Ratio of bank loans to legal } \\
\text { entities to GDP }\end{array}$ & 13.3 & 19.3 & 27.1 & 31.5 & 33.4 & 35.0 \\
\hline $\begin{array}{l}\text { Ratio of bank loans to } \\
\text { individuals to GDP }\end{array}$ & 1.0 & 3.5 & 8.5 & 9.3 & 13.4 & 13.3 \\
\hline
\end{tabular}

Source: Own processing based on data of Bank of Russia [22] and Federal State Statistic Service [23].

Assuming that the lending activity of banks is one of the factors of economic development, we analyzed to what extent the growth rate of loans to legal entities and individuals is reflected in the GDP and investment indices. The analysis shows that the dynamics of lending to legal entities almost coincide with the dynamics of total volume of lending. Trends in the growth rate of lending to individuals, on the contrary, often differ from this trajectory. Thus, in 2003, 2006, and 2010-2011, there was an increase in lending to individuals similar to the general dynamics of bank lending, but the actual growth rates of loans to individuals significantly exceeded the overall values of the corresponding indicators, which is primarily due to the more intensive development of consumer lending in comparison with corporate lending in these years. In other cases, trends in bank lending to individuals repeated trends in bank lending in general, but with some delay: while the decline in the overall growth rate of bank loans was observed in 2001-2002 and 2012-2013, the decline in the growth rate of loans to individuals occurred only in 2002 and 2013-2015. 
However, in certain periods of time, the dynamics of the consumer loans segment, on the contrary, outpaced the overall trajectory. Thus, the slowdown in the growth rate of loans to individuals in the pre-crisis period already began in 2007, while the overall rate of bank loans significantly decreased only a year later. Or, the observed gradual increase in the growth rate of loans to individuals during 2016-2018 was accompanied by a similar trend in the corporate loans segment only starting from 2017.

Comparing dynamics of the growth rates of bank loans with dynamics of GDP and investment indices, one can see that their trajectories are similar and are characterized by a decrease in values. The slowdown in lending dynamics is associated, in particular, with an increase in concentration in the banking sector [24]. The trajectory of changes in macroeconomic indices is more similar to the trajectory of growth rate of loans to legal entities, which indicates a closer dependence of economic development on dynamics of corporate lending than on dynamics of consumer lending.

As a follow-up to this idea, we will evaluate the impact of the ratio of bank loans to GDP on the dynamics of the studied macroeconomic indicators (Fig. 2). It is obvious that there is no similarity in trends between the growth rate of loans and the ratio of loans to GDP [25]. During the analyzed period 2000-2018, there was a gradual increase in the value of the ratio of loans to GDP from $11.6 \%$ at the end of 2000 to $46.5 \%$ at the end of 2018 . At the same time, over these years, the contribution of lending to individuals in this indicator has noticeably increased: if at the end of 2000 ratio of this segment to GDP was only $0.6 \%$, then at the end of 2018 it jumped to $14.3 \%$.

However, the GDP and investment indices in 2000-2018 did not show similar significant growth, moreover, the development of consumer lending was sometimes accompanied by a parallel decrease in the values of the GDP and investment indices. In this regard, it should be noted that some authors emphasize the risk of domination of short-term consumer loans in our country over long-term [26], and there are studies that prove that corporate lending has a more beneficial effect on economic growth than consumer lending. $[27,28]$.

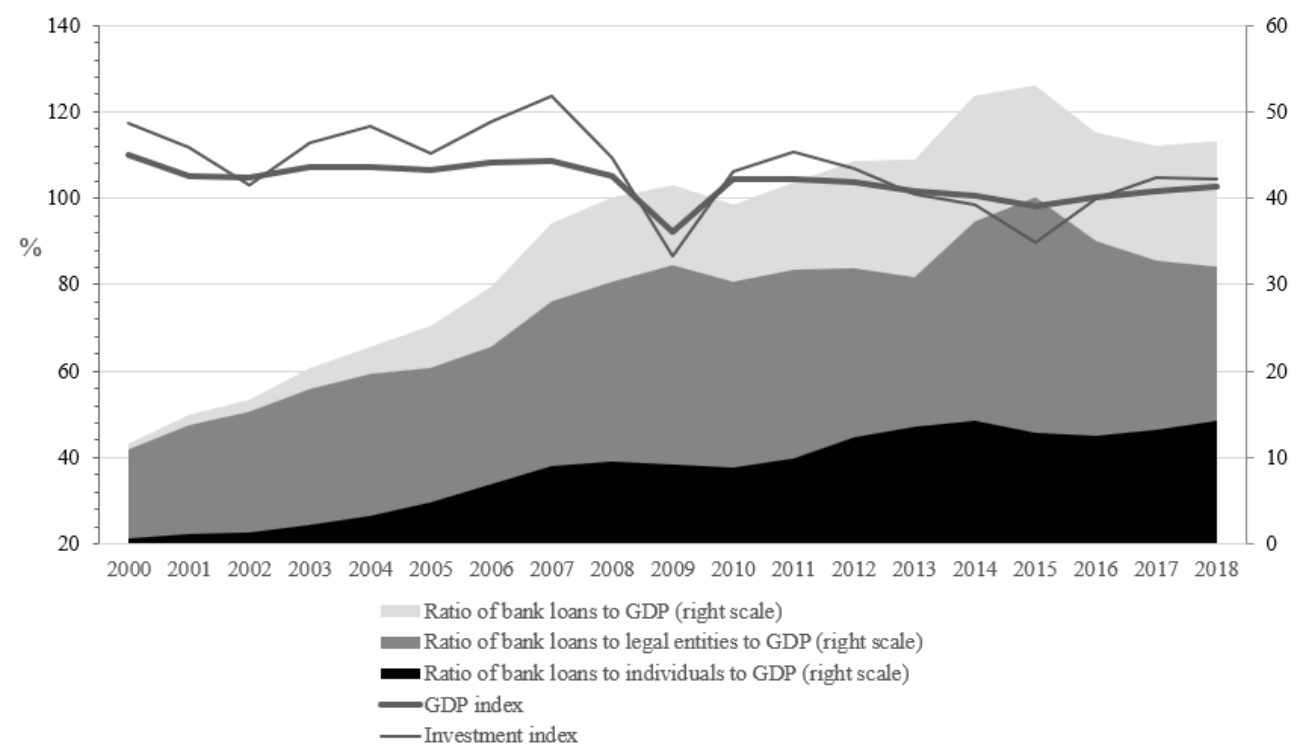

Fig. 2. Dynamics of GDP index, investment index and ratio of bank loans to GDP in Russia Source: Own processing based on data of Bank of Russia [22] and Federal State Statistic Service [23]. 
In support of this idea, we compared GDP and investment indices with the dynamics of share of loans in investment (Fig. 3).

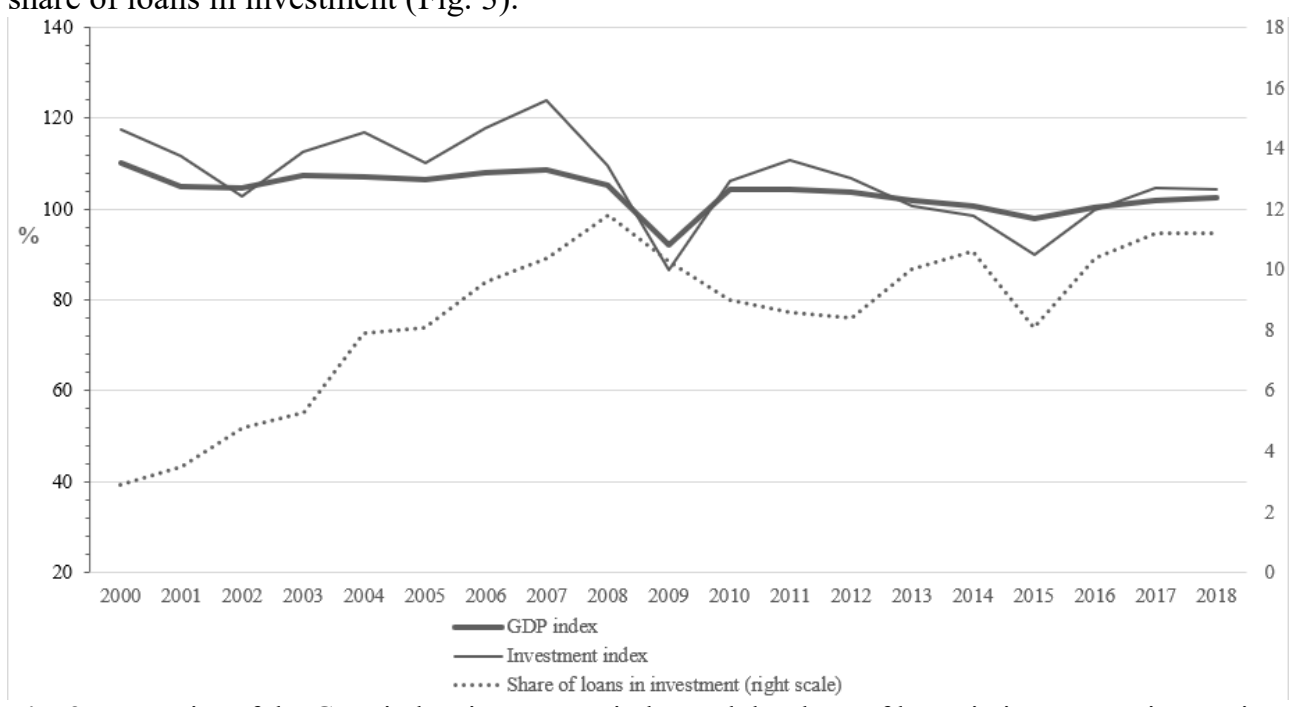

Fig. 3. Dynamics of the GDP index, investment index and the share of loans in investment in Russia Source: Own processing based on data of Bank of Russia [22] and Federal State Statistic Service [23].

The results of this analysis showed that changes in the share of loans in investment often affect growth rates of macroeconomic indices in about 2-3 years. For example, a noticeable increase in the share of loans in investment in 2000-2002, 2004, 2006-2008, and 2013-2014 was accompanied by an increase in macroeconomic indices in 2003-2004, 2006, 2010-2011, and 2016-2018, respectively. Conversely, the downward trend in the share of loans in investment in 1998-2000 and 2009-2012 may have influenced the decline in the values of macroeconomic indices in 2001-2002 and 2012-2015, respectively. A similar relationship is shown by a comparison of the dynamics of the average values of these indicators presented in Table 1. Thus, the increase of the average values in 2003-2005, 2006-2008, 2012-2014 compared to the previous three-year periods was observed for the macroeconomic indices, and the share of loans in investment. At the same time, in 20152018 , the average value of the share of loans in investment increased in comparison with the previous period, while the average values of macroeconomic indices decreased. In our opinion, the fact that in some cases an increase in the share of loans in investment is reflected in economic growth, and in others it is not, can be attributed primarily to the fact that this share itself, even despite the increase, may remain insignificant. This indicator would certainly have a more noticeable impact on economic growth if it reached the level of more than $20 \%$, as in developed countries, where it is equal to $30-50 \%$ [29].

\section{Conclusion}

Summarizing the results of the study, we can draw the following conclusions:

1. The trajectory of dynamics of GDP and investment indices in most cases coincides and has a general tendency to decrease the values, while the investment index is more sensitive to both crisis phenomena and the emergence of favorable conditions for economic development, including lending factors.

2. The dynamics of lending to legal entities almost coincides with the dynamics of total volume of lending, but trends in the growth rate of lending to individuals often differ from this trajectory. 
3. Economic indicators are more dependent on the development of bank lending to legal entities than on lending to individuals.

4. In most cases, there is a dependence of the GDP and investment indices on the share of loans in investments with a time lag of 2-3 years, however, there are facts that contradict this conclusion, which may be due to the low values of the share of loans in investment in Russia, which are insufficient to obtain a more noticeable impact on the economic growth.

5 . The revealed patterns of interrelation between bank lending indicators and general economic indicators indicate the need to develop a monetary policy aimed at stimulating corporate lending and moderate curbing consumer lending.

\section{References}

1. Russian Financial Market Development Program for 2019-2021 [online], Available at: https://www.cbr.ru/Content/Document/File/87952/fm_development_program_20192021.pdf (2019)

2. Н.Е. Бровкина, Развитие финансового рынка в контексте его кредитной составляющей. Банковские услуги, 10, с.10-16 (2019) [N.E. Brovkina, Development of the financial market in the context of its credit component. Banking services, 10, pp.10-16 (2019)].

3. Monetary Policy Guidelines for 2020-2022 [online], Available at: https://www.cbr.ru/eng/publ/ondkp/on_2020_2022/page/ (2019)

4. Э.Я. Брегель, А.С. Цаголов, Теория кредита. Москва: Госфиниздат (1933) [E.Ya. Bregel, A.S. Tsagolov, Theory of credit. Moscow: State Financial Publishing (1933)].

5. K. Marx. Capital. A critique of political economy, vol. 3: The process of capitalist production as a whole. New York: International Publishers (1894).

6. J.M. Keynes, The general theory of employment, interest and money. London: Macmillan (1936).

7. F.A. Hayek, Prices and production. London: Routledge (1935).

8. J. Huerta de Soto, The Austrian School: market order and entrepreneurial creativity. Cheltenham: Edward Elgar (2008).

9. Д.В. Бураков, Управление цикличностью движения кредита. Москва: Русайнс (2015) [D.V. Burakov, Credit cycle management. Moscow: Ru-Science (2015)].

10. D. Hancock, J.A. Wilcox, Has there been a "capital crunch" in banking? The effects on bank lending of real estate market conditions and bank capital shortfalls. Journal of housing economics, 3 (1), pp.31-50 (1993).

11. А.Г. Аганбегян, Инвестиционный кредит - главное звено преодоления спада в социально-экономическом развитии России. Деньги и кредит, 5, с.11-18 (2014) [A.G. Aganbegyan, Investment loan as a main link to overcome recession in Russia's socio-economic development. Money and credit, 5, pp.11-18 (2014)].

12. М.В. Антонова, Е.В. Кутищева, Роль банковского кредита в развитии экономики Липецкой области. Пермский финансовый журнал, 1, с.48-59 (2014) [M.V. Antonova, E.V. Kutischeva, Role of bank lending in economic development of Lipetsk region. Perm financial magazine, 1, pp.48-59 (2014)].

13. А.П. Вожжов, Е.Л. Гринько, С.П. Вожжов, Д.В. Черемисинова, Архитектоника финансового обеспечения и регулирования устойчивого и сбалансированного экономического роста. Москва: КНОРУС (2017) [A.P. Vozhzhov, E.L. Grinko, 
S.P. Vozhzhov, D.V. Cheremisinova, Architectonics of financial support and regulation of sustainable and balanced economic growth. Moscow: KNORUS (2017)].

14. Г.В. Кобылинская, Финансовое обеспечение инвестиционной деятельности и ее влияние на региональное развитие. Север и рынок: формирование экономического порядка, 3, c.134-144 (2018) [G.V. Kobylinskaya, Financial support to investment activities and its influence on regional development. The North and the Market: Forming the Economic Order, 3, pp.134-144 (2018)].

15. В.В. Маганов, Корреляционный анализ зависимости банковского кредита, сбережений и динамики валового внутреннего продукта. Научное обозрение, 8 (1), c.307-313 (2014) [V.V. Maganov, Correlation analysis of the dependence of bank credit, savings and the dynamics of gross domestic product. Scientific Review, 8 (1), pp.307-313 (2014)].

16. Б.В. Мдавар, Роль кредитования банковской системы Иордании в экономической деятельности страны. Экономика и предпринимательство, 11 (2), с.175-179 (2015) [B.V. Mdawar, The role of lending to the banking system of Jordan in the country's economic activity. Journal of Economy and Entrepreneurship, 11 (2), pp.175179 (2015)].

17. Н.Н. Столбовская, В.А. Максименко, Д.Г. Кулакова, Е.М. Коликова, Оиенка взаимосвязи динамики объемов банковского кредитования и объемов ВВП в России на основе применения метода регрессионного анализа. Финансовые исследования, 4, с.58-70 (2017) [N.N. Stolbovskaya, V.A. Maksimenko, D.G. Kulakova, E.M. Kolikova, Evaluation of the relationship between the dynamics of the volume of bank lending and GDP in Russia on the basis of the method of regression analysis. Financial Research, 4, pp.58-70 (2017)].

18. M.N. Ibrahim, M.E. Shah, Bank lending, macroeconomic conditions and financial uncertainty: evidence from Malaysia. Review of Development Finance, 2 (3-4), pp.156-164 (2012).

19. О.И. Лаврушин, Эволючия теории кредита и его использование в современной экономике. Москва: КНОРУС (2016) [O.I. Lavrushin, Evolution of credit theory and its use in modern economy. Moscow: KNORUS (2016)].

20. M. Garcia-Escribano, F. Han, Credit expansion in emerging markets: propeller of growth? IMF Working Paper, WP/15/212 (2015).

21. М. Мамонов, А. Пестова, В. Панкова, Р. Ахметов, О. Солнцев, Финансовый сектор, экономический рост и макроэкономическая стабильность. Банк России. Серия докладов об экономических исследованиях, 21 (2017) [M. Mamonov, A. Pestova, V. Pankova, R. Ahmetov, O. Solncev, Financial sector, economic growth and macroeconomic stability. Bank of Russia. Economic Research Report Series, 21 (2017)].

22. Bank of Russia [online], Available at: http://cbr.ru (2020)

23. Federal State Statistic Service [online], Available at: http://rosstat.gov.ru (2020)

24. С.М. Богомолов, Л.В. Ильина, Ю.Е. Копченко, Консолидаиия банковского сектора России: характеристика прочессов. Вестник Саратовского государственного социально-экономического университета, 3, с.101-105 (2018) [S.M. Bogomolov, L.V. Ilyina, Yu.E. Kopchenko, Consolidation of banking sector in Russia: characterization of processes. Bulletin of Saratov State Socio-Economic University, 3, pp.101-105 (2018)].

25. С.М. Богомолов, М.В. Плотникова, Банковская политика в области обеспечения качества кредитных услуг и направления ее сбалансированности. Интеллект. 
Инновации. Инвестиции, 6, с.25-31 (2019) [S.M. Bogomolov, M.V. Plotnikova, Banking policy of ensuring quality of credit services and the direction of its balance. Intellect. Innovation. Investments, 6, pp.25-31 (2019)].

26. О.Е. Кузина, Н.А. Крупенский, Перекредитованность россиян: миф или реальность? Вопросы экономики, 11, с.85-104 (2018) [O.E. Kuzina, N.A. Krupenskiy, Over-indebtedness of Russians: myth or reality? Economic Issues, 11, pp.85-104 (2018)].

27. T. Beck, B. Büyükkarabacak, F. Rioja, N.N. Valev, Who gets the credit? And does it matter? Household vs. firm lending across countries. The B.E. Journal of Macroeconomics, 12 (1), pp.1-46 (2012).

28. L. Florian, Enterprise credit, household credit and growth: new evidence from 126 countries. Luxembourg: University of Luxembourg (2016).

29. А.Г. Аганбегян, Размышления о финансовом форсаже (по мотивам книги «Финансовые стратегии модернизащии экономики: мировая практика»). Деньги и кредит, 8, с.5-10 (2015) [A.G. Aganbegyan, Reflections on financial boosting (on the motives of the book "Financial strategies for economic modernisation: global practice”). Money and credit, 8, pp.5-10 (2015)]. 